\title{
VARIABILITY OF SOYBEAN GERMPLASM IN RELATION TO PHOSPHORUS UPTAKE AND USE EFFICIENCY ${ }^{1}$
}

\author{
Ângela Maria Cangiani Furlanii,5*; Pedro Roberto Furlanii 2,5 Roberto Tetsuo Tanaka ${ }^{3,5}$; Hipólito \\ Assunção Antonio Mascarenhas ${ }^{3,5}$; Margarida das Dores Paes Delgado ${ }^{4}$ \\ ${ }^{2}$ Centro de Pesquisa e Desenvolvimento de Solos e Recursos Agroambientais / IAC, C.P. 28 - CEP: 13001-970 - \\ Campinas, SP. \\ ${ }^{3}$ Centro de Análise e Pesquisa Tecnológica do Agronegócio dos Grãos e Fibras / IAC. \\ ${ }_{5}^{4}$ Graduate trainee - Centro de Pesquisa e Desenvolvimento de Solos e Recursos Agroambientais / IAC. \\ ${ }^{5} \mathrm{CNPq}$ Fellow. \\ *Corresponding author <afurlani@barao.iac.br>
}

ABSTRACT: Plant efficiency for phosphorus uptake and utilization may contribute to improve crop yield potential in situations of low $\mathrm{P}$ availability. Twenty nine soybean [Glycine max (L.) Merr.] cultivars were evaluated and classified in relation to the response to phosphorus $(P)$ levels in nutrient solution. $P$ uptake and use efficiency were estimated by the variables: shoot and root dry matter (DM) yield, P-concentrations and contents in plant parts and P-efficiency index (EI). The experiment was conducted in a greenhouse, during 1999, at Campinas, State of São Paulo, Brazil. The experimental design consisted of randomized complete blocks, arranged in splitplots, with three replications. The main plots were the $\mathrm{P}$ levels in the nutrient solution $(64.5 ; 129 ; 258$ and 516 $\mathrm{mmol} \mathrm{L}^{-1}$ ), and the subplots were the twenty-nine soybean cultivars, grouped according days to maturity. The plants were harvested at flowering, separated in shoots and roots for dry matter determination and chemical analysis. The analyses of variance indicated differences in plant responses to P-levels and cultivars. Multivariate analysis showed high correlation among the variables shoot-DM, total-DM and shoot P-concentration and Pefficiency index (EI). Cultivars were classified in efficient-responsive (ER)- 'IAC-1', 'IAC-2', 'IAC-4', 'IAC-5', 'IAC6', 'IAC-9', 'Sta. Rosa' and 'UFV-1'; efficient-non-responsive (ENR) - 'IAC-7', 'IAC-11', 'IAC-15', 'S. Carlos' and 'Cristalina'; inefficient-responsive (IR) - 'IAC-8', 'IAC-10', 'IAC-14', 'Bossier' and 'Foscarin'; and inefficient-nonresponsive (INR) - 'IAC-12', 'IAC-13', 'IAC-16', 'IAC-17', 'IAC-18', 'IAC-19', 'IAC-20', 'IAC-22', 'Paraná', 'IAS-5' and 'BR-4'. The efficient-responsive soybean cultivars showed the highest values for shoot and total DM and EI, and the lowest shoot P-concentrations.

Key words: Glycine max (L.) Merr., cultivar, P-efficiency index, P-uptake, P-use

\section{VARIABILIDADE EM GERMOPLASMA DE SOJA PARA EFICIÊNCIA NA ABSORÇÃO E UTILIZAÇÃO DE FÓSFORO}

\begin{abstract}
RESUMO: A eficiência da planta na absorção e utilização de fósforo em situação de baixa disponibilidade do nutriente pode contribuir para aumentar o potencial produtivo da cultura. Vinte e nove cultivares de soja [G/ycine max (L.) Merr.] foram avaliados e classificados quanto à resposta a concentrações de fósforo (P) em solução nutritiva. Determinaram-se as variáveis relacionadas com a eficiência na absorção e utilização de P: produção de matéria seca (MS) da parte aérea e das raízes, teores de $\mathrm{P}$ nas partes das plantas e os índices de eficiência de utilização de $P$ (IE). O experimento foi instalado em casa de vegetação em Campinas, em 1999. Foi utilizado o delineamento em blocos ao acaso, em parcelas subdivididas com três repetições. As parcelas principais constituíram-se das concentrações de $\mathrm{P}$ na solução nutritiva $\left(64,5 ; 129 ; 258\right.$ e $\left.516 \mathrm{mmol} \mathrm{L}^{-1}\right)$ e as subparcelas, dos vinte e nove cultivares de soja, agrupados de acordo com o ciclo. As plantas foram colhidas no florescimento, separadas em parte aérea e raízes para determinação da matéria seca e análise química de nutrientes. A análise de variância indicou diferenças nas respostas das plantas para concentrações de $P$ e cultivares. A análise multivariada mostrou alta correlação entre a MS de parte aérea e MS-total com os teores de $\mathrm{P}$ na parte aérea e índices de eficiência de utilização de $P$ (IE). Os cultivares foram classificados em eficientes e responsivos (ER) - 'IAC-1', 'IAC-2', 'IAC-4', 'IAC-5', 'IAC-6', 'IAC-9', 'Sta. Rosa' e 'UFV-1'; eficientes não responsivos (ENR) - 'IAC-7', 'IAC-11', 'IAC-15', 'S. Carlos' e 'Cristalina'; ineficientes responsivos (IR) - 'IAC-8', 'IAC-10', 'IAC-14', 'Bossier' e 'Foscarin'; e ineficientes não responsivos (INR) - 'IAC-12', 'IAC-13', 'IAC-16', 'IAC-17', 'IAC-18', 'IAC-19', 'IAC-20', 'IAC-22', 'Paraná', 'IAS-5' e 'BR-4'. Os cultivares eficientes e responsivos mostraram os maiores valores para MS de parte aérea, MS total e IE, e os menores teores de $P$ na parte aérea.

Palavras-chave: Glycine max (L.) Merr., cultivar, índice de eficiência ao P, absorção de P, utilização de P
\end{abstract}

\section{INTRODUCTION}

Phosphorus is a major limiting factor for crop production of many tropical and subtropical soils. In Brazilian soils, high productivities of soybean are achieved by soil amendment techniques, using lime and fertilizers, supplying the nutrients required for best crop performance. The yield potential is an intrinsic factor and depends on plant germplasm characters that can be modified by selection and breeding.

${ }^{1}$ Paper presented in the XIV International Plant Nutrition Colloquium, Hannover, Germany, 2001. 
Plant efficiency for nutrient uptake and utilization may improve yield potential in situations of soil nutrient stress, reducing plant demands for a given level of crop yield. The search for efficient plants in nutrient uptake and use has been stimulated since large genetic variability was reported for these characters within germplasm of several species (De Mooy, 1973; Gabelman, 1976; Gerloff, 1976; Clark \& Duncan 1991; Spehar, 1995a, b; Ciarelli et al., 1998; Furlani et al., 1998; Dechen et al., 1999; Bahia-Filho et al., 1997; Furlani \& Machado, 2000).

Differences in grain yield among soybean cultivars for phosphorus $(\mathrm{P})$, potassium $(\mathrm{K})$ and $\mathrm{N}$ efficiencies were also reported by Raper \& Barber (1970); De Mooy et al. (1973); Sabbe \& Delong (1998); Sarawgi \& Tripathi (1998); Hanumanthappa et al. (1998; 1999) and Ogburia et al. (1999), in field experiments.

Spehar (1995a, b; 1999) studied genetic differences in the accumulation of nutrients in leaves and seeds of tropical soybean cultivars from diallel crosses with the cultivars IAC-9, IAC-2, UFV-1, IAC-5, IAC-8, Vx5-281, IAC-7, Biloxi and Cristalina under high and low Al-stress. The diallel analysis indicated that an additive-dominance model could explain the genetic differences among those genotypes for nutrient accumulation in leaves and seeds. The diallel analysis, although not conclusive, indicated that the mechanisms of mineral element accumulation in the leaves are not fully associated to those of accumulation in the seeds of soybeans. The expression of these characters is, however, dependent on mineral plantstress.

Nutrient solution techniques have been used as important tools in short-term experiments to select and identify nutrient-efficient and Al-tolerant plants (Furlani \& Furlani, 1988; 1989; Spehar \& Galwey, 1995; 1997; Ciarelli et al., 1998; Furlani et al., 1998; Spehar \& Souza, 1999). In addition, these might be non-destructive techniques that allow taking selected seedlings to the field, when germplasm seed availability is low.

The objective of this research was to select and classify twenty-nine soybean cultivars in relation to the response to $P$ levels in short-term nutrient solution experiments, to determine germplasm variability. P-uptake and use efficiency were estimated by the variables: shoot and root dry matter yield, $\mathrm{P}$ concentrations and contents in plant parts and P-efficiency index.

\section{MATERIAL AND METHODS}

\section{Experimental design and treatments}

The experiment was carried out in a greenhouse of the Central Experiment Station of the Instituto Agronômico (IAC), at Campinas, State of São Paulo, Brazil, during 1999-2000. Treatments were 29 soybean cultivars, grown under four rates of $P$ in nutrient solution, with three replications. The experimental design was a randomized complete block arranged in split-plots. The main plots were the $P$ rates and the sub-plots, the soybean cultivars. The main plots consisted of the following $P$ rates: $64.5 ; 129 ; 258$ and $516 \mathrm{mmol} \mathrm{L}^{-1}$. Cultivars were grouped according to days to maturity: (1) early (up to 120 days) - 'IAC-13', 'IAC-16', 'IAC-17', 'IAC20', 'IAC-22', 'Paraná', 'BR-4', 'IAS-5', 'Foscarin 31-1'; (2) mid-early (120 - 130 days) - 'IAC-1', 'IAC-10', 'IAC-12', 'IAC-15', 'IAC-18', 'Bossier' and 'São Carlos'; (3) mid (130 - 140 days) - 'IAC-2', 'IAC-4', 'IAC-5', 'IAC-8', 'IAC-11', 'IAC-14', 'IAC-19', 'Santa Rosa'; (4) mid-late (140 - 150 days) - 'IAC-6', 'IAC-7', 'IAC-9', 'UFV-1' and 'Cristalina'.

\section{Growing system}

Each plot consisted of four 25-L plastic recipients connected to a 100-L recipient (a total of $200 \mathrm{~L}$ nutrient solution). The experiment consisted of 12 plots, 48 subplots and demanded 2,400 liters of nutrient solution. The four recipients were calibrated to $25-\mathrm{L}$ by adjusting the height of a central sink, through which nutrient solution returns to the under table recipient. The 25-L recipients were provided with lids containing nine $2.5-\mathrm{cm}$-holes to support the plants. The under table $100-\mathrm{L}$ recipient was provided with a pump to circulate the nutrient solution upwards, intermittently, for 20 minutes, with 10 minute intervals, controlled by a 24 -hour timer. The intermittent circulation provided a more homogeneous solution and sufficient aeration for plant roots.

\section{Handling of nutrient solutions}

The base nutrient solution (Clark, 1982) was modified by Furlani \& Furlani (1988), using p.a. reagents and deionized water. The nutrient solution composition maintained during plant growth (average of 60 analysis, in mmol L-1) was: $\mathrm{N}-\mathrm{NO}_{3}=8.0 ; \mathrm{N}-\mathrm{NH}_{4}=1.14 ; \mathrm{K}=2.58$; $\mathrm{Ca}=3.07 ; \mathrm{Mg}=0.82 ; \mathrm{S}=2.93$; in $\mathrm{mmol} \mathrm{L}^{-1}-\mathrm{B}=26 ; \mathrm{Cl}$ $=931 ; \mathrm{Cu}=1.7 ; \mathrm{Fe}=82.4 ; \mathrm{Mn}=12.9 ; \mathrm{Zn}=4.9$; and $\mathrm{Mo}$ $=0.8 ; \mathrm{P}$ was added in four doses $(64.5 ; 129 ; 258$ and $516 \mathrm{mmol} \mathrm{L}^{-1}$ ).

The initial $\mathrm{pH}$ was 5.1 and remained about 4.8 during plant growth (average of 60 measurements), and the electrical conductivity was about $1,400 \mathrm{mS}$. The nutrient solution was sampled for chemical analysis, at the beginning of the experiment and on four other occasions. The nutrient solution was replenished 14 days and 30 days after transplant, when nutrients were about 60 and $70 \%$ of the initial concentrations, respectively, using proportional volumes of the balanced stock solutions. The nutrient depletion occurred slowly because of the large volume of solution available to the plants.

\section{Handling of plants}

Seeds were germinated between moist paper towels in a germination chamber at $25^{\circ} \mathrm{C}$. Seven-day-old uniform-sized seedlings were transplanted to the $25-\mathrm{L}$ recipients, grouped according cultivar's cycle. In each recipient, two seedlings/hole were suspended in the nutrient solution from lids holding plants of nine cultivars. 
Each plot had $200 \mathrm{~L}$ of nutrient solution for 72 plants, corresponding to $2.8 \mathrm{~L}$ of solution per plant or $5.6 \mathrm{~L}$ per cultivar.

Fifteen days after transplanting, strings were suspended from the upper part of the greenhouse structure to hold plant shoots, to guide and support them during growth. The following procedures were performed daily or in alternate days: adjustment of nutrient solution levels of the under table recipients to the 100-L level with deionized water; root separation per cultivar; $\mathrm{pH}$ and electrical conductivity monitoring; maximum and minimum air temperature and relative humidity recording. The conditions in the greenhouse during plant growth were: photoperiod 12 hours; maximum day temperature $=35$ $\pm 4^{\circ} \mathrm{C}$; minimum night temperature $=19 \pm 2^{\circ} \mathrm{C}$; minimum day relative humidity: $19 \pm 13 \%$; maximum night relative humidity: $66 \pm 13 \%$.

At the end of the experiment, plants were harvested $45\left(1^{\text {st }} \mathrm{cycle}\right), 46$ ( $\left.2^{\text {nd }} \mathrm{cycle}\right), 47$ ( $\left.3^{\text {rd }} \mathrm{cycle}\right)$ and 48 ( $4^{\text {th }}$ cycle) days after imposing treatments, separated into shoots and roots, rinsed in deionized water, blotted dry in paper towels and dried at $70{ }^{\circ} \mathrm{C}$ in a forced-air oven. The following measurements were made: dry matter (DM) yield of plant parts; P-concentrations and $\mathrm{P}$-contents in plant parts; shoot/root ratio of $\mathrm{P}$-content; P-use efficiency index (EI) according to Siddiqi \& Glass $(1981)-E I=\left[(\text { total DM })^{2} /\right.$ total P-content $]$; other nutrient concentrations in plant parts. $P$ and other nutrient analysis in the ashes of dry tissues were performed by ICP-AES according to the routine used in the Laboratory of Soil and Plant Analysis of Instituto Agronômico (IAC).

For the classification, two variables were plotted for each cultivar: in the $Y$-axis, the efficiency index in the lower P-level and in the $\mathrm{X}$-axis, the ratio between the maximum and the minimum dry matter yield obtained for each cultivar. The average value in the $Y$ and $X$-axis defined the four groups: efficient-responsive (ER), inefficient-responsive (IR), efficient non responsive (ENR) and inefficient-non-responsive (INR). Data were subjected to analysis of variance for each variable, in a split-plot, using multiple regression analysis for the evaluation of cultivar response to $P$ levels and multivariate analysis for the evaluation of the main variables and the correlations among them.

\section{RESULTS AND DISCUSSION}

Plants showed differences during vegetative growth. Severe P deficiency symptoms were recorded for plants grown under the lower $\mathrm{P}$ concentration in solution $\left(64.5 \mathrm{mmol} \mathrm{L}^{-1}\right)$, characterized by smaller leaves, yellowing and premature senescence of older leaves. Differences in growth, size and color of leaves were observed among $P$ treatments. Plants from the other $P$ treatments $\left(129 ; 258\right.$ and $\left.516 \mathrm{mmol} \mathrm{L}^{-1}\right)$ showed better development, larger and greener leaves.
Analysis of variance indicated highly significant $F$ values for the P-levels and cultivars, for shoot dry matter (shoot DM), root dry matter (root DM), total dry matter (total DM), dry matter shoot/root ratio (shoot/root $D M)$, shoot $P$-concentration (shoot $[P]$ ), root $P$ concentration (root $[\mathrm{P}]$ ), shoot $\mathrm{P}$-content, root $\mathrm{P}$-content, total P-content, shoot/root ratio of P-content (shoot/root $P)$ and the efficiency index (E.I.), calculated according Siddiqi \& Glass (1981). The coefficients of variation for the main plots (P-levels) were between 4.0 and $6.9 \%$ and for the subplots (cultivars), between 24.6 and $30.2 \%$. The relatively high $\mathrm{CV} \%$ obtained for cultivars might be explained by the small number of individuals per subplot, since the soybean germplasm used were improved varieties selected from populations.

The multivariate analysis was based on the main components that resulted in the dispersion graph presented in Figure 1. The synthetic variables in this Figure plotted for the analysis of main components, were originated from measurements in shoots and roots of plants, for the four P-levels. The dispersion represents the main plain formed by the axis 1 (horizontal) and axis 2 (vertical), evidencing the maximum of visual information. These two axes explained $75.8 \%$ of the total variability of the experiment $(52.8 \%$ in axis 1 and $23.0 \%$ in axis 2). Most of the variables are well represented and show high correlation with these two axes, that explain great proportion of the variability among soybean germplasm for the P-efficiency parameters: shoot DM, $r$ $=99 \%$; total DM, $r=94 \%$; shoot/root DM, $r=82 \%$; shoot $[P], r=94 \%$; root $[P]=73 \%$; shoot P-content, $r=96 \%$; total $P$ - content, $r=95 \%$; El, $r=91 \%$. The points for these variables are located in the dispersion graph far from and in the outside area of the axes. The variables not well correlated with the two axes were: root DM, $r=59 \%$; root $P$ content, $r=13 \%$ and shoot/root $P, r=43 \%$. The latter, are located close to the axes and in the inside graph area (Figure 1).

The position of the genotypes within the dispersion graph may be better understood by the direction in which the initial variables are disposed in the bidimensional plain (Philippeau, 1986). Therefore, the genotypes located above axis 1 (horizontal) presented the highest average values in the four $P$ levels. The genotypes located below the axis 1 presented the lowest average values for the same variables. The genotypes located at the right side of axis 2 (vertical) are mostly the ones evaluated for the P1 and P2 levels, and those located at the left side of axis 2 , are the ones evaluated for the P3 and P4 levels.

The average response of genotypes to P-levels and the dispersion for the cultivars within each P-level is also shown in Figure 1. A larger dispersion, obtained for the P3 level, suggests that this was the best P-level to identify genotypic differences.

Plant response and maximum yield varied among cultivars (Figure 2). Most soybean cultivars had their 
maximum total DM yields in the P3 level $\left(258 \mathrm{mmol} \mathrm{L}^{-1}\right)$, however the maximum shoot/root DM occurred in the P4 level (Figure 2). The shoot/root DM varied from 6.23 to 9.83 in the P3 level and from 6.23 to 12.73 in the P4 level. This is interpreted as shoot growth occurred in detriment of root growth in the P4 level. Shoot/root DM correlated with the axes 1 and 2 and with the P-efficiency characters (Figures 1 and 3 ), showing that the best yielding cultivars had higher shoot/root ratio DM.

Most cultivar responses in shoot and total dry matter yield to $\mathrm{P}$-levels fit a quadratic regression equation. And most cultivars presented the highest values for dry matter of shoot parts in the P3 level $(258 \mathrm{mmol} P$ $\mathrm{L}^{-1}$ in the nutrient solution) (Figure 1 and 2 ).
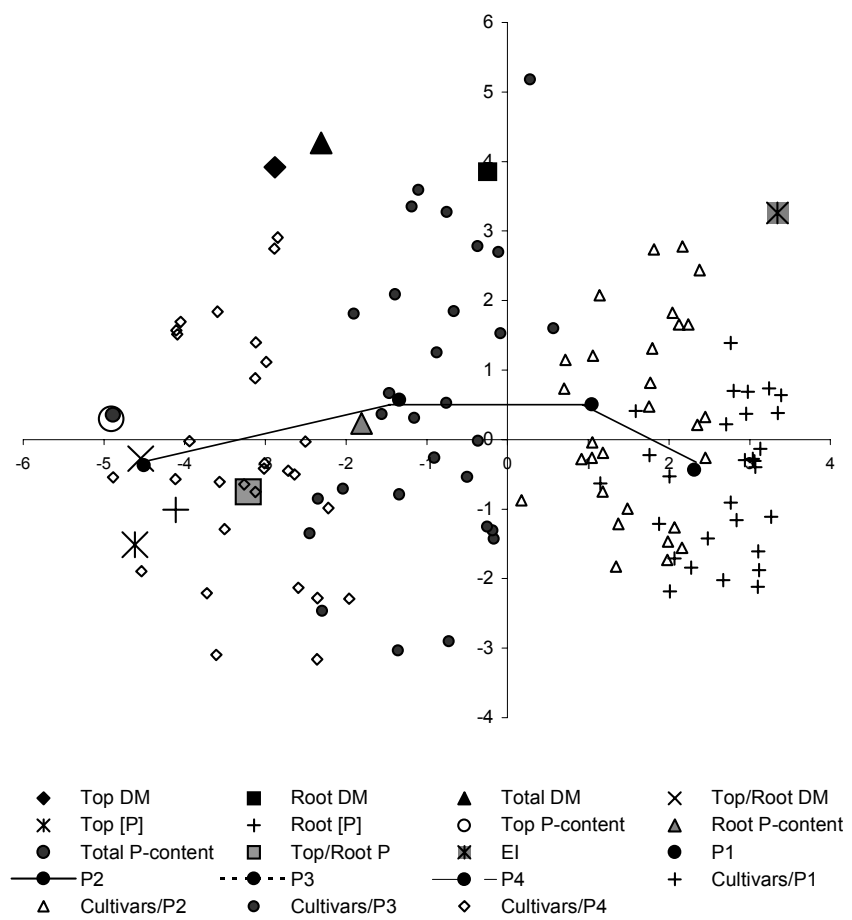

Figure 1 - Multivariate analysis of variables determined in 29 soybean cultivars grown in nutrient solution with four $\mathrm{P}$ concentrations $(\mathrm{P} 1=0.0645 ; \mathrm{P} 2=0.129 ; \mathrm{P} 3=0.258$ and $\left.\mathrm{P} 4=0.516 \mu \mathrm{mol} \mathrm{L}^{-1}\right)$.

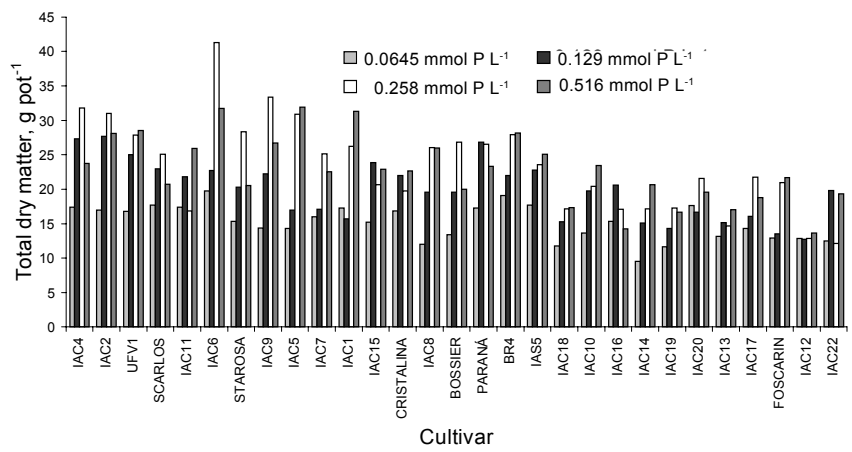

Figure 2 - Total dry matter yield (shoots and roots) obtained for 29 soybean cultivars grown in nutrient solution with four $P$ concentrations. Analysis of variance: $\mathrm{F}(\mathrm{P}$-dosis $)=55.1^{\star *}$; $\mathrm{F}($ cult $)=7.4^{* *} ; \mathrm{F}(\mathrm{P} \times$ cult $) 1.3^{*} ; \mathrm{CV}(\mathrm{P}$-dosis $)=4,3 \%$; CV (cult) $=23,8 \%$; ${ }^{* *}$ significant at $P<0.01$; ${ }^{*}$ significant at $P<0.07$. Regression: $\mathrm{R}^{2}$ (quadr) $=0.95^{\star *}$
P-concentrations in the dry tissue of shoots and roots increased with increasing $P$-levels and were inversely proportional to the dry matter yields, what was expected due to dilution effect (Tables 1 and 2). The multivariate analysis showed that the shoot $[\mathrm{P}]$ was highly and negatively correlated with the P-efficiency index (E.I.) $(r=-0.795)$, meaning that most efficient plants showed lower P-concentration in the shoots. These variables together with shoot and total DM explained most of the variability within soybean germplasm for the P-efficiency characters (Figure 1). Other researchers have reported low nutrient concentration or accumulation in the plant tissue as a nutrient efficiency character (Barber et al., 1967; Baker et al., 1970; 1971; Spehar \& Souza, 1999). Barber et al. (1967) observed genetic controlled variations in $\mathrm{P}$-accumulation in maize. Hybrids resulted from crossing of low $\mathrm{P}$-accumulation inbred lines were also low accumulators, and those resulted from crossing of high P-accumulation inbred lines, were high accumulators. Baker et al. $(1970,1971)$ found differences among hybrids for the leaf $\mathrm{P}$-accumulation and grain yield and confirmed the high heritability for this character. The leaf $P$ accumulation was not correlated with plant ability in Puptake, but was associated to physiological processes independent of roots. Spehar \& Souza (1999) selected and bred soybean genotypes for Ca-efficiency under low Ca nutrient solution conditions, searching for plants with lower requirement for this nutrient, adapted to Cerrado soils.

$\mathrm{P}$-contents in shoots and roots increased with increasing $\mathrm{P}$-levels in the nutrient solution. Shoot Pcontents (in mg per 2 plants) varied from 33.0 ('IAC-19') to 70.2 ('IAC-16') for the P3 level and from 51.9 ('IAC19 ') to 110.4 ('IAC-1' and 'Paraná') for the P4 level (Tables 3 and 4). 'Paraná', 'IAC-1' and 'BR-4' presented the highest total P-contents (Figure 4). The interaction cultivars $x$ P-levels was not significant for the variables shoot $\mathrm{P}$-content, root $\mathrm{P}$-content and total $\mathrm{P}$-content. Although the analysis of variance has shown significant interaction (cultivar $x$ P-levels) for the variable shoot/root $P$ ratio (Figure 5), the multivariate analysis showed that the shoot/root $\mathrm{P}$ ratio was not well correlated with the other variables ( $r=43 \%)$, what means that the variation observed among cultivars for the $\mathrm{P}$ distribution in shoots and roots was not well correlated with the variation observed for the other variables. In despite of this, shoot and total $\mathrm{P}$-contents were important variables highly correlated to axes 1 and 2, except for root P-content (Figure 1). Although the total P-contents had significant variation, this variation was more related to the increasing $\mathrm{P}$-levels than to the variability within cultivars, maybe due to small number of plants per subplot. For this reason, in this experiment, the total $\mathrm{P}$-contents are not well correlated to the other P-efficient characters $[r$ $=0.51$ (total $\mathrm{P} \times$ total DM); and $\mathrm{r}=-0.60$ (total $\mathrm{P} \times \mathrm{EI}$ )], as seen in Figure 1, where shoot $P$, root $P$ and total $P$ contents are closely located to the axis- 1 . 
Table 1 - P concentrations in the shoot dry matter of 29 soybean cultivars grown in nutrient solutions with four P-levels.

\begin{tabular}{|c|c|c|c|c|c|}
\hline \multirow[t]{2}{*}{ Cultivar } & \multicolumn{4}{|c|}{$\begin{array}{l}\text { P-treatment in the nutrient } \\
\text { solution }\left(\mathrm{mmol} \mathrm{L}^{-1}\right)\end{array}$} & \multirow[t]{2}{*}{ Mean } \\
\hline & 0.0645 & 0.129 & 0.258 & 0.516 & \\
\hline \multicolumn{6}{|c|}{----- $\mathrm{mg} \mathrm{kg}^{-1}$----- } \\
\hline IAC-22 & 1.72 & 1.80 & 4.69 & 5.37 & 3.39 \\
\hline IAC-16 & 1.48 & 1.70 & 4.60 & 5.73 & 3.38 \\
\hline IAC-13 & 1.59 & 1.92 & 4.67 & 4.47 & 3.17 \\
\hline Paraná & 1.64 & 1.43 & 2.75 & 5.30 & 2.78 \\
\hline IAC-20 & 1.49 & 1.83 & 3.66 & 4.42 & 2.85 \\
\hline IAC-17 & 1.41 & 2.35 & 3.48 & 5.32 & 1.14 \\
\hline Foscarin & 1.43 & 1.62 & 3.23 & 4.79 & 2.77 \\
\hline IAC-12 & 0.95 & 1.88 & 3.33 & 5.51 & 2.92 \\
\hline IAS- 5 & 1.87 & 1.72 & 2.64 & 4.16 & 2.60 \\
\hline BR-4 & 1.69 & 1.81 & 2.67 & 4.37 & 2.64 \\
\hline IAC-1 & 0.95 & 1.93 & 2.92 & 4.22 & 2.50 \\
\hline IAC-14 & 0.99 & 1.35 & 3.18 & 3.90 & 2.35 \\
\hline IAC-7 & 0.84 & 1.55 & 2.28 & 4.36 & 2.26 \\
\hline IAC-15 & 0.90 & 1.03 & 2.62 & 4.45 & 2.25 \\
\hline IAC-10 & 0.97 & 1.67 & 2.66 & 3.87 & 2.23 \\
\hline IAC-18 & 1.05 & 1.16 & 2.30 & 4.23 & 2.19 \\
\hline Cristalina & 0.72 & 1.23 & 2.47 & 4.07 & 2.12 \\
\hline Bossier & 0.97 & 0.97 & 2.00 & 4.32 & 2.07 \\
\hline S. Carlos & 0.84 & 0.95 & 2.35 & 4.06 & 2.05 \\
\hline IAC-11 & 0.74 & 0.97 & 3.07 & 3.10 & 1.97 \\
\hline Sta. Rosa & 0.79 & 1.15 & 1.87 & 3.79 & 1.90 \\
\hline IAC-19 & 0.82 & 1.19 & 2.09 & 3.44 & 1.88 \\
\hline AC-4 & 0.86 & 0.91 & 2.01 & 3.75 & 1.88 \\
\hline IAC-2 & 0.77 & 0.97 & 2.00 & 3.77 & 1.88 \\
\hline AAC-6 & 0.71 & 1.60 & 1.14 & 3.21 & 1.88 \\
\hline IAC-9 & 0.81 & 1.11 & 1.73 & 3.65 & 1.83 \\
\hline UFV-1 & 0.76 & 0.84 & 1.75 & 3.16 & 1.63 \\
\hline AC-5 & 0.81 & 1.06 & 1.68 & 2.72 & 1.57 \\
\hline AC- 8 & 0.75 & 0.88 & 1.54 & 2.86 & 1.51 \\
\hline Mean & 1.09 & 1.72 & 2.67 & 4.15 & \\
\hline
\end{tabular}

Analysis of variance: $F(P$-dosis $)=82.4^{* *} ; F($ cult $)=9.0^{* *} ; F(P \times$ cult $)$ $=1.4^{*} ; \mathrm{CV}(\mathrm{P}$-dosis $)=11.3 \% ; \mathrm{CV}$ (cult) $=30.1 \%$; ${ }^{* *}$ significant at $P<$ 0.01 ; * significant at $P<0.05$. Regression for P-levels: $\mathrm{R}^{2}$ (linear) $=$ $0.97^{* *}$.

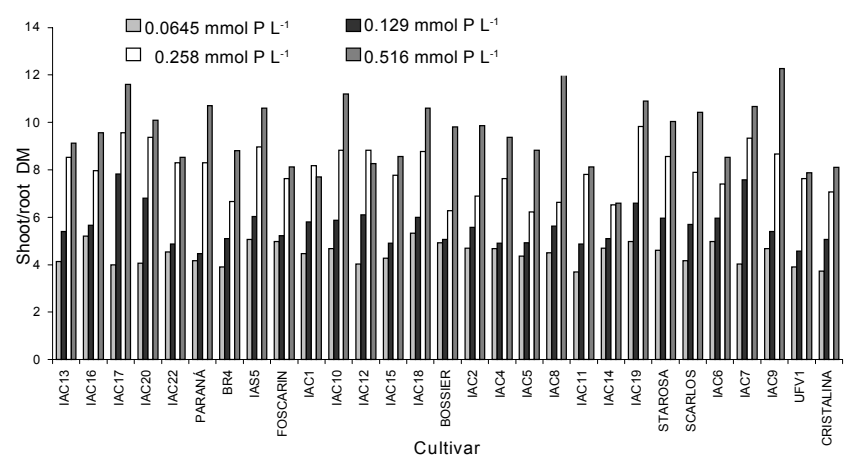

Figure 3 - Shoot/root ratio of dry matter (DM) of 29 soybean cultivars grown in nutrient solution with four $\mathrm{P}$ concentrations. Analysis of variance: $F(P$-dosis $)=126.4^{* *} ; \mathrm{F}$ (cult $)=2.8^{* *}$; $\mathrm{F}(\mathrm{P} \times$ cult $)=1.01$ ns; $\mathrm{CV}(\mathrm{P}$-dosis $)=5.1 \% ; \mathrm{CV}$ (cult $)=$ $20,8 \%$; ${ }^{* *}$ significant at $P<0.01$; ns non-significant. Regression: $\mathrm{R}^{2}$ (quadr.) $=0.99^{\star *}$.
Table 2 - P concentrations in the dry matter of roots of 29 soybean cultivars grown in nutrient solutions with four P-levels.

\begin{tabular}{|c|c|c|c|c|c|}
\hline \multirow[t]{2}{*}{ Cultivar } & \multicolumn{4}{|c|}{$\begin{array}{l}\text { P-treatment in the nutrient } \\
\text { solution }\left(\mathrm{mmol} \mathrm{L}^{-1}\right)\end{array}$} & \multirow[t]{2}{*}{ Mean } \\
\hline & 0.0645 & 0.129 & 0.258 & 0.516 & \\
\hline & \multicolumn{5}{|c|}{ 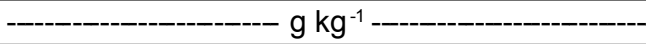 } \\
\hline IAC-16 & 1.01 & 1.54 & 2.05 & 8.47 & 3.27 \\
\hline IAC-7 & 1.09 & 1.92 & 2.17 & 7.00 & 3.04 \\
\hline IAC-17 & 1.17 & 1.69 & 2.13 & 7.43 & 3.11 \\
\hline IAC-20 & 0.79 & 1.28 & 2.63 & 7.07 & 2.97 \\
\hline Cristalina & 0.79 & 1.38 & 1.98 & 6.59 & 2.69 \\
\hline IAC-22 & 0.98 & 1.22 & 2.74 & 5.39 & 2.58 \\
\hline Foscarin & 0.83 & 1.44 & 1.71 & 6.25 & 2.56 \\
\hline S. Carlos & 1.01 & 1.07 & 1.81 & 6.01 & 2.48 \\
\hline IAC-12 & 0.86 & 1.30 & 2.11 & 4.95 & 2.30 \\
\hline IAC-14 & 1.05 & 1.22 & 2.48 & 4.20 & 2.24 \\
\hline IAC-13 & 0.98 & 1.30 & 1.99 & 4.48 & 2.19 \\
\hline IAC-18 & 1.06 & 1.11 & 2.04 & 4.51 & 2.18 \\
\hline IAC-9 & 0.81 & 1.61 & 1.49 & 4.37 & 2.07 \\
\hline IAC-4 & 0.99 & 1.10 & 2.17 & 4.96 & 2.06 \\
\hline IAC-10 & 0.99 & 1.09 & 2.14 & 4.74 & 1.99 \\
\hline Paraná & 0.86 & 0.94 & 1.08 & 5.23 & 2.03 \\
\hline IAC-19 & 1.09 & 1.14 & 2.08 & 4.96 & 2.07 \\
\hline Bossier & 0.95 & 0.97 & 1.62 & 4.53 & 2.02 \\
\hline UFV-1 & 0.88 & 1.12 & 1.69 & 4.36 & 2.01 \\
\hline IAS-5 & 1.03 & 1.46 & 1.55 & 4.00 & 2.01 \\
\hline Sta. Rosa & 0.88 & 1.24 & 1.59 & 4.31 & 2.01 \\
\hline IAC-1 & 0.94 & 1.24 & 2.24 & 3.21 & 1.91 \\
\hline BR-4 & 0.84 & 1.20 & 1.46 & 4.56 & 2.01 \\
\hline IAC-15 & 0.89 & 1.07 & 2.14 & 3.66 & 1.94 \\
\hline IAC-2 & 0.89 & 1.01 & 1.56 & 3.87 & 1.85 \\
\hline AC- 6 & 1.38 & 1.83 & 1.38 & 2.37 & 1.74 \\
\hline ACC-8 & 0.98 & 1.11 & 1.66 & 3.20 & 1.74 \\
\hline IAC-5 & 0.97 & 1.21 & 1.57 & 3.09 & 1.71 \\
\hline IAC-11 & 0.90 & 1.03 & 2.24 & 2.62 & 1.69 \\
\hline Means & 0.96 & 1.29 & 1.96 & 4.79 & \\
\hline
\end{tabular}

Analysis of variance: $F(P$-dosis $)=105.6^{* *} ; F($ cult $)=2.21^{* *} ; F(P x$ cult $)=1.47^{*} ; \mathrm{CV}$ (P-dosis) $=13.0 \% ; \mathrm{CV}$ (cult) $=47.4 \%$; ${ }^{*}$ significant at $P<0.01$; * significant at $P<0.05$. Regression for $P$-dosis: $\mathrm{R}^{2}$ (quadr.) $=0.99^{*}$.

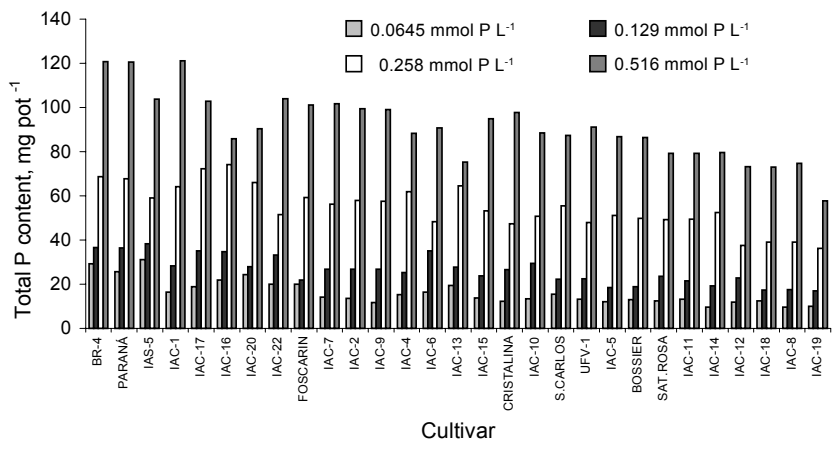

Figure 4 - Total P content of 29 soybean cultivars grown in nutrient solution with four $\mathrm{P}$ concentrations. Analysis of variance: $F(P$-dosis $)=156.1^{* *} ; F($ cult $)=6.3^{* *} ; F(P \times$ cult $)=1.04$ ns; CV $($ P-dosis $)=9.9 \% ;$ CV (cult) $=25.1 \% ;{ }^{* *}$ significant at $P<0.01$; ${ }^{n s}$ non-significant. Regression: $R^{2}$ (linear) $=$ $0.98^{* *} ; R^{2}$ (quadr.) $=0.99^{*}$. 
Table 3 - Shoot $\mathrm{P}$ contents in 29 soybean cultivars grown in nutrient solutions with four P-levels.

\begin{tabular}{|c|c|c|c|c|c|}
\hline \multirow[t]{2}{*}{ Cultivar } & \multicolumn{4}{|c|}{$\begin{array}{l}\text { P-treatment in the nutrient } \\
\text { solution }\left(\mathrm{mmol} \mathrm{L}^{-1}\right)\end{array}$} & \multirow[t]{2}{*}{ Mean } \\
\hline & 0.0645 & 0.129 & 0.258 & 0.516 & \\
\hline & \multicolumn{5}{|c|}{--_----------- mg P (2 plants) ---_-_--------- } \\
\hline Paraná & 22.8 & 32.1 & 64.1 & 110.4 & 57.4 \\
\hline BR-4 & 25.8 & 33.1 & 63.3 & 108.8 & 57.8 \\
\hline IAS-5 & 28.2 & 33.6 & 55.4 & 95.3 & 53.1 \\
\hline IAC-17 & 15.5 & 34.7 & 67.8 & 91.9 & 51.7 \\
\hline AC-1 & 13.3 & 25.4 & 57.8 & 110.4 & 51.7 \\
\hline IAC-16 & 19.4 & 29.9 & 70.2 & 74.4 & 48.5 \\
\hline IAC-20 & 21.0 & 24.9 & 61.2 & 78.1 & 40.3 \\
\hline IAC-22 & 17.7 & 29.4 & 48.1 & 92.9 & 47.0 \\
\hline Foscarin & 15.1 & 18.6 & 55.2 & 88.9 & 44.5 \\
\hline IAC-13 & 16.8 & 24.6 & 61.6 & 67.7 & 42.7 \\
\hline AC-2 & 10.7 & 22.5 & 51.8 & 90.1 & 43.8 \\
\hline IAC-7 & 10.6 & 22.7 & 50.7 & 88.4 & 43.1 \\
\hline IAC-9 & 9.6 & 21.0 & 51.4 & 90.3 & 43.1 \\
\hline IAC-6 & 11.8 & 29.1 & 41.2 & 82.9 & 41.3 \\
\hline IAC-15 & 11.1 & 19.3 & 48.2 & 86.6 & 41.3 \\
\hline IAC-4 & 12.2 & 20.2 & 52.5 & 79.4 & 41.1 \\
\hline IAC-10 & 10.9 & 26.3 & 46.5 & 81.4 & 41.3 \\
\hline S. Carlos & 12.0 & 18.4 & 50.2 & 76.6 & 39.3 \\
\hline Cristalina & 9.4 & 22.0 & 42.6 & 81.4 & 38.9 \\
\hline Bossier & 10.8 & 15.6 & 44.0 & 77.8 & 37.0 \\
\hline UFV-1 & 10.2 & 17.3 & 42.3 & 78.3 & 37.0 \\
\hline Sta. Rosa & 9.9 & 20.0 & 44.8 & 71.2 & 36.5 \\
\hline IAC-5 & 9.5 & 14.8 & 44.5 & 76.6 & 36.4 \\
\hline IAC-11 & 9.9 & 17.6 & 45.2 & 71.7 & 36.1 \\
\hline IAC-14 & 7.8 & 16.2 & 46.8 & 68.4 & 34.8 \\
\hline IAC-12 & 9.7 & 20.5 & 34.5 & 66.1 & 32.7 \\
\hline IAC-18 & 10.4 & 14.9 & 35.5 & 66.4 & 31.8 \\
\hline AC- 8 & 7.3 & 14.3 & 33.4 & 68.5 & 30.9 \\
\hline IAC-19 & 7.9 & 14.8 & 33.0 & 51.9 & 26.9 \\
\hline Mea $^{(2)}$ & 13.4 & 22.5 & 49.8 & 81.8 & \\
\hline
\end{tabular}

${ }^{(1)}$ Analysis of variance: $F(P$-dosis $)=115.6^{* *} ; F($ cult $)=6.22^{* *} ; F(P x$ cult $)=1.05 \mathrm{~ns} ; \mathrm{CV}$ (P-dosis $)=11.8 \% ; \mathrm{CV}$ (cult) $=27.2 \%$; ${ }^{* *}$ significant at $P<0.01$; *significant at $P<0.05$; ns $=$ non-significant. Regression for P-dosis: $R^{2}$ (quadr.) $=0.99^{*}$.

The efficiency index (EI), calculated for each cultivar, decreasing with the increased P-levels was expected (Figure 6). This index evaluates the amount of dry matter produced for a given P-concentration in the plant dry tissue and maximum El are usually found at low P-levels. Some cultivars showed highest El in the P2level, showing good performance in both $\mathrm{P} 1$ and $\mathrm{P} 2$ levels. The relevant aspect is that there were large differences among cultivars ( 3 to 5 times) for the $\mathrm{EI}$ determined in the lower P-levels. The analysis of variance showed highly significant cultivar $\times$ P-level interactions and significant mean differences among cultivars within each P-level (Figure 6).

The multivariate analysis showed that shoot- and total-DM and the P-efficiency indices (EI) were highly and positively correlated, and negatively correlated with the P-concentration in the dry matter of shoots and roots.
Table 4 - Root $P$ contents in 29 soybean cultivars grown in nutrient solutions with four $\mathrm{P}$-levels.

\begin{tabular}{|c|c|c|c|c|c|}
\hline \multirow[t]{2}{*}{ Cultivar } & \multicolumn{4}{|c|}{$\begin{array}{l}\text { P-treatment in the nutrient } \\
\text { solution }\left(\mathrm{mmol} \mathrm{L}^{-1}\right)\end{array}$} & \multirow[t]{2}{*}{ Mean } \\
\hline & 0.0645 & 0.129 & 0.258 & 0.516 & \\
\hline & \multicolumn{5}{|c|}{ 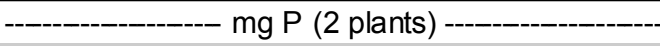 } \\
\hline Cristalina & 2.81 & 4.65 & 4.73 & 16.28 & 7.12 \\
\hline AC-7 & 3.44 & 4.09 & 5.62 & 13.40 & 6.64 \\
\hline UFV-1 & 3.01 & 5.05 & 5.63 & 14.00 & 6.93 \\
\hline AC-4 & 3.07 & 5.13 & 9.30 & 8.95 & 6.61 \\
\hline AC- 6 & 4.57 & 5.97 & 7.03 & 7.83 & 6.35 \\
\hline IAC-9 & 2.09 & 5.67 & 6.21 & 8.80 & 5.69 \\
\hline BR-4 & 3.33 & 3.50 & 5.37 & 12.02 & 6.06 \\
\hline IAC-20 & 3.33 & 2.97 & 4.93 & 12.35 & 5.90 \\
\hline S. Carlos & 3.50 & 3.73 & 5.30 & 10.77 & 5.83 \\
\hline AC-1 & 3.03 & 2.80 & 6.33 & 10.87 & 5.76 \\
\hline AC-5 & 2.63 & 3.57 & 6.57 & 10.17 & 5.73 \\
\hline IAC-16 & 2.50 & 4.80 & 3.97 & 11.40 & 5.67 \\
\hline AC-2 & 2.90 & 4.30 & 6.10 & 9.33 & 5.66 \\
\hline IAC-17 & 3.30 & 3.53 & 4.45 & 10.87 & 5.54 \\
\hline IAC-14 & 1.75 & 2.94 & 5.75 & 11.18 & 5.41 \\
\hline Foscarin & 1.90 & 3.13 & 4.13 & 12.20 & 5.34 \\
\hline Paraná & 2.91 & 4.40 & 3.62 & 10.30 & 5.31 \\
\hline IAS-5 & 3.00 & 4.70 & 3.63 & 8.57 & 4.98 \\
\hline IAC-22 & 2.21 & 3.79 & 3.37 & 11.10 & 5.12 \\
\hline Bossier & 2.13 & 3.23 & 5.70 & 8.70 & 4.94 \\
\hline IAC-15 & 2.60 & 4.53 & 5.10 & 8.19 & 5.11 \\
\hline IAC-11 & 3.27 & 3.80 & 4.23 & 7.53 & 4.71 \\
\hline Sta. Rosa & 2.43 & 3.60 & 4.57 & 8.00 & 4.65 \\
\hline IAC-10 & 2.40 & 3.06 & 4.30 & 7.17 & 4.23 \\
\hline IAC-8 & 2.17 & 3.23 & 5.63 & 6.30 & 4.33 \\
\hline IAC-13 & 2.57 & 3.10 & 3.00 & 7.50 & 4.04 \\
\hline IAC-12 & 2.20 & 2.39 & 3.11 & 7.18 & 3.72 \\
\hline IAC-18 & 1.97 & 2.47 & 6.61 & 6.54 & 3.65 \\
\hline IAC-19 & 2.13 & 2.17 & 3.30 & 5.97 & 3.39 \\
\hline Mean $^{(2)}$ & 2.73 & 3.80 & 5.09 & 9.77 & \\
\hline
\end{tabular}

Analysis of variance: $F(P$-dosis $)=217.3^{* *} ; F$ (cult $)=2.64^{* *} ; F(P x$ cult $)=1.23 \mathrm{~ns} ; \mathrm{CV}$ (P-dosis) $=6.93 \% ; \mathrm{CV}$ (cult) $=39.9 \%$; ** significant at $P<0.01$; ${ }^{*}$ significant at $P<0.05$; ns $=$ non-significant. Regression for P-dosis: $R^{2}$ (quadr.) $=0.99^{*}$.

This means that, for soybeans, low $P$ concentrations in shoots correlate with highly P-efficient genotypes. These variables explained most of the variability within soybean germplasm for the P-efficiency characters (Figure 1).

In an attempt to group the germplasm, each of the 29 cultivars was plotted comparing the P-efficiency index in the lower P-level $\left(64.5 \mathrm{mmol} \mathrm{P} \mathrm{L}^{-1}\right)$ in the $\mathrm{Y}$-axis, against the proportional increase in dry matter yield obtained for each cultivar (DMmax/DMmin) in the X-axis (Figure 7). The average values for the means in the $Y$ and $X$ axes defined the four cultivars groups: ER = efficient-responsive, IR = inefficient-responsive, ENR = efficient-non-responsive; INR = and inefficient-nonresponsive. Cultivars were considered to be efficient, when the P-efficiency indices were above the average for the $\mathrm{P} 1$ level $\left(64.5 \mathrm{mmol} \mathrm{P} \mathrm{L}^{-1}\right)$ and responsive those that had maximum dry matter yields above the average. The 


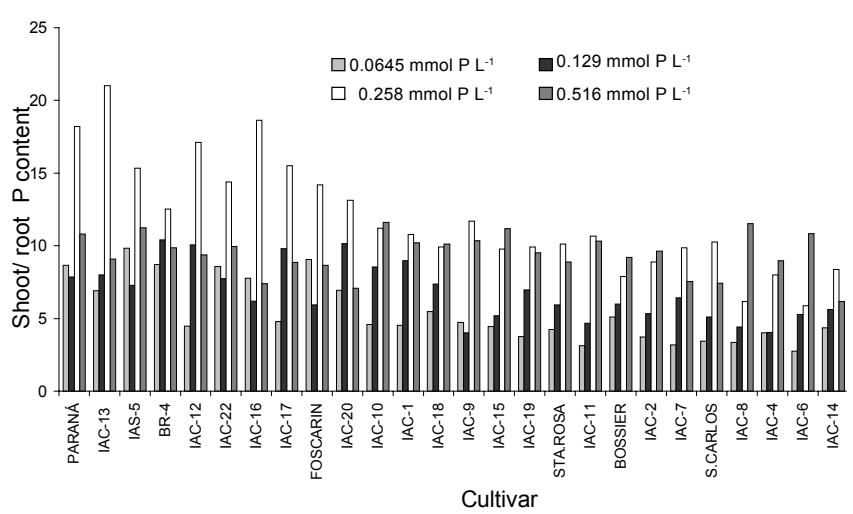

Figure 5 - Shoot/ root $\mathrm{P}$ content ratio of 29 soybean cultivars grown in nutrient solution with four $P$ concentrations. Analysis of variance: $F(P$-dosis $)=14.8^{* *} ; F$ (cult $)=2.9^{* *} ; F(P x$ cult $)=1.85^{\star *} ; \mathrm{CV}$ (P-dosis $)=18.7 \% ; \mathrm{CV}$ (cult) $=77.5 \%$; ** significant at $P<0.01$. Regression: $\mathrm{R}^{2}$ (quadr.) $=0.87^{* *}$

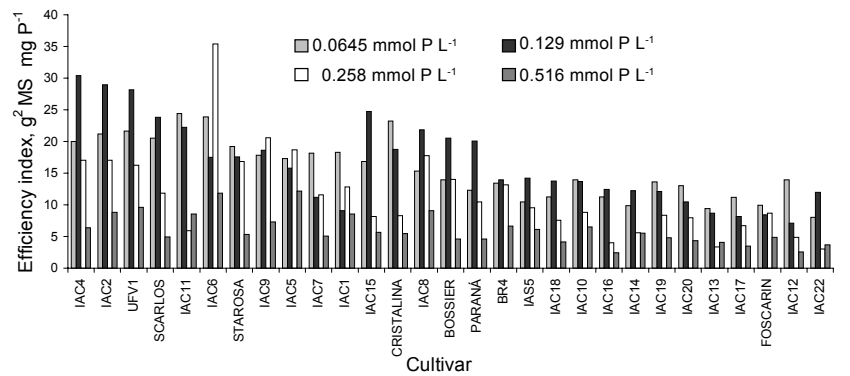

Figure 6 - Efficiency index of 29 soybean cultivars grown in nutrient solution with four $P$ concentrations. Analysis of variance: $\mathrm{F}(\mathrm{P}$-dosis $)=38.6^{\star *} ; \mathrm{F}($ cult $)=8.7^{* *} ; \mathrm{F}(\mathrm{P} \times$ cult $)=1.69^{\star *}$; CV $(P$-dosis $)=10.7 \%$; CV (cult) $=39.9 \%$; ${ }^{* *}$ significant at $P<0.01$. Regression: $\mathrm{R}^{2}$ (linear) $=0.94^{\star *}$.

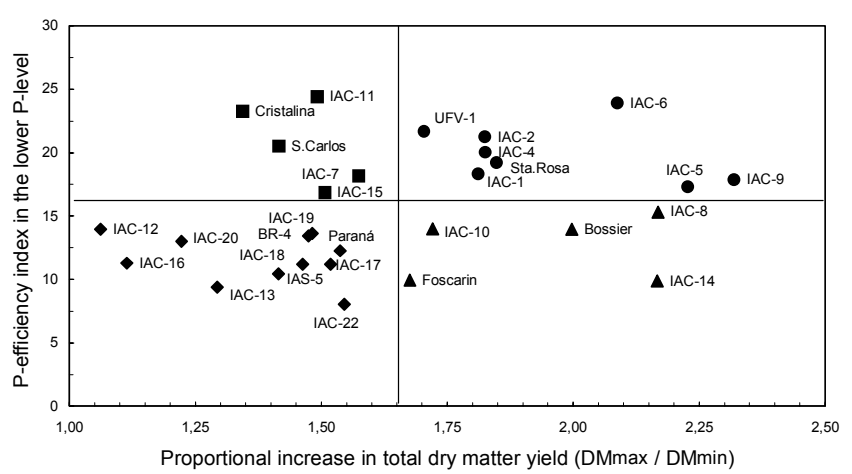

Figure 7 - Classification of twenty nine soybean cultivars for the efficiency index (EI) in the lowest $P$ concentration in the nutrient solution $\left(64.5 \mathrm{mmol} \mathrm{L}^{-1} \mathrm{P}\right)$ and the proportional increase in total dry matter yield (DMmax/DMmin) in response to the P-levels: efficient-responsive (ER); efficient non-responsive (ENR); inefficient responsive (IR); inefficient non-responsive (INR). Early cycle (up to 120 days): 'IAC-13', 'IAC-16', 'IAC-17', 'IAC-20', 'IAC-22', 'Paraná', 'BR-4', 'IAS-5', 'Foscarin 31-1'; mid-early cycle (120 - 130 days) - 'IAC-1', 'IAC-10', 'IAC-12', 'IAC-15', 'IAC-18', 'Bossier' and 'São Carlos'; mid cycle (130 140 days) - 'IAC-2', 'IAC-4', 'IAC-5', 'IAC-8', 'IAC-11', 'IAC-14', 'IAC-19', 'Santa Rosa'; and mid-late cycle (140 - 150 days) - 'IAC-6', 'IAC-7', 'IAC-9', 'UFV-1' and 'Cristalina'. cultivars classified as efficient-responsive (ER) were: 'IAC1', 'IAC-2', 'IAC-4', 'IAC-5', 'IAC-6', 'IAC-9', 'Sta. Rosa' and 'UFV-1'; efficient-non-responsive (ENR): 'IAC-7', 'IAC-11', 'IAC-15', 'S. Carlos' and 'Cristalina'; inefficient-responsive (IR): 'IAC-8', 'IAC-10', 'IAC-14', 'Bossier' and 'Foscarin'; and inefficient-non-responsive (INR) - 'IAC-12', 'IAC-13', 'IAC-16', 'IAC-17', 'IAC-18', 'IAC-19', 'IAC-20', 'IAC-22', 'Paraná', 'IAS-5' and 'BR-4' (Figure 7).

Differences among soybean cultivars as to their efficiency in $P$ uptake and use were evident in this experiment. The best cultivars presented the highest dry matter yields, the highest P-efficiency indices and the lowest P-concentrations in the shoot dry matter. Most of the early and mid-early cultivars were classified as Pinefficient germplasm, except IAC-1, IAC-15 and S. Carlos. Most of the mid and late maturity genotypes were classified as P-efficient cultivars except IAC-14 and IAC19.

Although fresh dry matter has not been measured in this experiment, it would probably be highly correlated with dry matter yield and could be useful in population screening when seed availability is limited. At the flowering stage when plants would be harvested, it is suggested that branches could be separated and propagated vegetatively. This would allow harvesting seeds of desirable individuals for subsequent screening procedures.

\section{CONCLUSIONS}

Soybean cultivars differed in P-efficiency characters.

According to P-efficiency indices and the response to $\mathrm{P}$-levels, eight cultivars were considered $\mathrm{P}$ efficient and responsive (ER); five were efficient nonresponsive (ENR); five were inefficient responsive (IR) and eleven were inefficient non-responsive (INR).

P-efficient and responsive (ER) cultivars showed the highest values for shoot and total dry matter yield and P-efficiency index; and the lowest values for shoot Pconcentration.

\section{ACKNOWLEDGEMENTS}

To FAPESP and CNPq for financial support. To Dr. Oliveiro Guerreiro Filho for the contribution in the statistical multivariate analysis and to Alice Castaldi Sampaio for the participation and dedication in experiments, lab analysis and data computer analysis.

\section{REFERENCES}

BAHIA FILHO, A.F.C.; MAGNAVACA, R.; SCHAFFERT, R.E.; ALVES, V.M.C. Identification, utilization, and economic impact of maize germplasm tolerant to low levels of phosphorus and toxic levels of exchangeable aluminum in Brazilian soils. In: MONIZ, A.C.; FURLANI, A.M.C.; SCHAFFERT, R. et al. (Eds.) Plant-soil interactions at low pH: sustainable agriculture and forestry production. Campinas: Sociedade Brasileira de Ciência do Solo, 1997. p.59-70. 
BAKER, D.E.; JARREL, A.E.; MARSHAL, L.E.; THOMAS, W.I. Phosphorus uptake from soils by corn hybrids selected for high and low phosphorus accumulation. Agronomy Journal, v.62, p.103-106, 1970.

BAKER, D.E.; WOODING, F.J.; JOHNSON, M.W. Chemical element accumulation by populations of corn (Zea mays L.) selected for high and low accumulation of P. Agronomy Journal, v.63, p.404-406, 1971.

BARBER, W.D.; THOMAS, W.I.; BAKER, D.E. Inheritance of relative phosphorus accumulation in corn (Zea mays L.) Crop Science, v.7, p.104107,1967

CIARELLI, D.M.; FURLANI, A.M.C.; DECHEN, A.R.; LIMA, M. Genetic variation among maize genotypes for P-uptake and P-use efficiency in nutrient solution. Journal of Plant Nutrition, v.21, p.2219-2229, 1998.

CLARK, R.B. Nutrient solution growth of sorghum and corn in mineral nutrition studies. Journal of Plant Nutrition, v.5, 1039-1057, 1982.

CLARK, R.B.; DUNCAN, R.R. Improvement of plant mineral nutrition through breeding. Field Crops Research, v.27, p.219-240, 1991.

DE MOOY, C.J.; PESEK, J.; SPALDON, E. Mineral Nutrition. In: CALDWELL, B.E. (Ed.) Soybeans: improvement, production, and uses. Madison: ASA, 1973. p.267-352.

DECHEN, A.R.; FURLANI, A.M.C.; FURLANI, P.R. Tolerance and adaptation of plants to nutrient stress (text in Portuguese). In: SIQUEIRA, J.O.; MOREIRA, F.M.S.; LOPES, A.S.; GUILHERME, L.R.G.; FAQUIN, V. FURTINI-NETO, A.E.; CARVALHO, J.G. (Ed.) Inter-relação fertilidade, biologia do solo e nutrição de plantas. Viçosa: SBCS; Lavras: UFLA/ DCS, 1999. p. 337- 361.

FURLANI A.M.C.; FURLANI, P.R. Composition and pH of nutrient solutions for physiological studies and plant selection under adverse nutritional conditions. Campinas: Instituto Agronômico. 34p. 1988. (Boletim Técnico, 121).

FURLANI, A.M.C.; LIMA, M.; NASS, L.L. Combining ability effects for P efficiency characters in maize grown in low $\mathrm{P}$ nutrient solution. Maydica, v.43, p.169-174, 1998

FURLANI, A.M.C.; MACHADO, C.T.T. Eficiência de plantas na utilização de nutrientes em ambientes marginais. Especificidade genética e herança das características relativas à eficiência a fósforo. (Compact disc). In: FertBio 2000, Santa Maria, 2000. Santa Maria: UFSM; SBCS, 2000.

FURLANI, P.R.; FURLANI, A.M.C. Estresse nutricional: técnicas de seleção de plantas em apoio ao melhoramento genético. In: REUNIÃO BRASILEIRA DE FISIOLOGIA VEGETAL, 2., Piracicaba, 1989. Anais... Piracicaba: Sociedade Brasileira de Fisiologia Vegetal; ESALQ, 1989. p.9399.

GABELMAN, W.H. Genetic potentials in nitrogen, phosphorus, and potassium efficiencies. In: WRIGHT, M.J. (Ed.) Plant adaptation to mineral stress in problem soils. Ithaca: Cornell University Agricultural Experiment Station, 1976. p.205-212.

GERLOFF, G.C. Plant efficiencies in the use of nitrogen, phosphorus, and potassium. In: WRIGHT, M.J. (Ed.) Plant adaptation to mineral stress in problem soils. Ithaca: Cornell University Agricultural Experiment Station, 1976. p.161-173.
HANUMANTHAPPA, M.; HOSMANI, S.A.; SREERAMULU, K.R J. Effect of different levels of phosphorus on yield and yield components of soybean varieties. Agricultural Science Digest, v.18, p.140-142, 1998.

HANUMANTHAPPA, M.; SREERAMULU, K.R.; NAIK, R.G. Influence of phosphorus levels on dry matter production and yield in soybean varieties. Journal of Maharashtra Agricultural Universities, v.23, p.195-196, 1999.

OGBURIA, M.N.; ATABAEVA, H.N.; HASSANSHIN, R.U. Evaluation of varietal response of soybean (Glycine max L. Merril) to nitrogen $(N)$ fertilization in Tashkent, Central Asia. Acta Agronomica Hungarica, v.47, p.329-333, 1999.

PHILIPPEAU, G. Comment interpréter les résultats d'une analyse en composantes principales? Paris: Service des Etudes Statistiques- ITCF, 1986. 64p.

RAPER JR., C.D.; BARBER, S.A. Rooting System of Soybeans. II. Physiological effectiveness as nutrient absorption surfaces. Agronomy Journal, v.62, p.585-588, 1970.

SABBE, W.E.; DELONG R. E. Influence of phosphorus plus potash fertilizer and irrigation on grain yields of soybean cultivars. Arkansas: Arkansas Experiment Station, 1998. (Research Series, 459).

SARAWGI, S.K.; TRIPATHI, R.S. Yield and economics $f$ soybean (Glycine max L. Merril) varieties in relation to phosphorus level. Journal of Oilseeds Research, v.15, p.363-365, 1998.

SIDDIQI, M.Y.; GLASS A.D.M. Utilization index: A modified approach to the estimation and comparison of nutrient utilization efficiency in plants. Journal of Plant Nutrition, v.4, p.289-302, 1981.

SPEHAR, C.R. Genetic differences in the accumulation of mineral elements in seeds of tropical soybeans Glycine max (L.) Merril. Pesquisa Agropecuária Brasileira, v.30, p.89-94, 1995a.

SPEHAR, C.R. Diallel analysis for mineral element absorption in tropical adapted soybeans (Glycine max L. Merril). Theoretical and Applied Genetics, v.90, p.707-713, 1995b.

SPEHAR, C.R. Diallel analysis for grain yield and mineral absorption rate of soybeans grown in acid Brazilian Savannah soil. Pesquisa Agropecuária Brasileira, v.34, p.1003-1009, 1999.

SPEHAR, C.R.; GALWEY, N.W. Generation mean analysis of root-growth under aluminum-stress hydroponics in the soybeans (Glycine max L. Merril). Pesquisa Agropecuária Brasileira, v.30, p.963-970, 1995.

SPEHAR, C.R.; GALWEY, N.W. Screening soya beans (Glycine max L. Merril) calcium efficiency by root growth in low-Ca nutrient solution. Euphytica, v.94, p.113-117, 1997.

SPEHAR, C.R.; SOUZA, L.A.C. Selecting soybean (Glycine max L. Merril) tolerant to low-calcium stress in short term hydroponics experiment. Euphytica, v.106, p.35-38, 1999.

Received February 08, 2002 